\title{
RAVNOPRAVAN TRETMAN SUPERIORNIH, PROSJEČNIH I DJECE S TEŠKOĆAMA U RAZVOJU U SAVREMENOJ ŠKOLI
}

\section{SAŽETAK}

$U$ teoriji $i$ praksi savremenog odgojno-obrazovnog rada nezaobilazna su pitanja koja tretiraju rad djece s posebnim potrebama. Pod ovim pojmom se najčešće misli na učenike koji iz bilo kojih razloga zaostaju u praćenju nastave, u izvršavanju školskih obaveza i ostvarivanju pozitivnih ishoda učenja. Malo ili gotovo nikako se ne vrši razgraničenje ovih $i$ onih drugih učenika kod kojih su posebne potrebe izraz želje za većom spoznajom, za produktivnijim $i$ plodotvornijim radom $i$ učenjem. Nastavnici u težnji da zadovolje zahtjeve nastavnog plana $i$ programa, redovno svoju pažnju usmjeravaju na prvu kategoriju učenika ne ostavljajući prostora $i$ vremena za one druge, koji su nam jednako važni kao i ovi. 'Jesu li superiorni učenici zapostavljeni u našim školama?', pitanje je koje se s jasnim razlogom nameće - radi njih i njihove budućnosti.

Ključne riječi: emocionalna stabilnost, inkluzija, integracija, ishodi učenja, kreativnost, nadareni, obdareni, optimizam, posebne potrebe, talenti, teškoće u razvoju.

\section{Uvod}

Škola kao odgojno-obrazovna ustanova pruža učenicima znanja, razvija im sposobnosti, formira kod učenika vještine i navike. To je jedan od osnovnih preduvjeta da škola ostvari svoju funkciju i osigura učenicima pretpostavke za uspjeh u životu i radu.

U razvoju i formiranju ličnosti učenika podjednaku ulogu i značaj imaju faktori naslijeđa, utjecaja sredine, te faktori odgoja i aktivnosti pojedinaca. Zato je značajno osigurati takvu klimu u školi, koja će uvažavati sve faktore u razvoju ličnosti i podsticati njihov utjecaj. Biološka osnova svake ličnosti dana je nervnim i endokrinim

\footnotetext{
${ }^{1}$ Pedagoški fakultet u Bihaću
} 
sistemom, tjelesnom konstitucijom. Svi oni zajedno u osnovi čine nasljednu komponentu. Socijalni faktori kao porodica i uvjeti života i rada u porodici, rodbina, poznanici, vršnjaci, škola, razne organizacije, kulturni život sredine te mas-mediji i literatura, također imaju veoma značajnu ulogu u razvoju ličnosti.

Kada govorimo o posebnim potrebama učenika u učionici, ne smijemo izgubiti iz vida činjenicu da gotovo sva djeca imaju određene posebne potrebe. Međutim, i djeca odlični i vrlo dobri učenici imaju određene posebne potrebe u skladu sa svojim interesima, željama, mogućnostima i sposobnostima. Tako imaju potrebu za organiziranim bavljenjem određenim aktivnostima prema kojima imaju sklonosti i afinitet kao što su: muzičke, likovne, sportske aktivnosti, aktivnosti bavljenja literarnim stvaralaštvom, učešce u radu naučno-predmetnih grupa kao mladi matematičari, fizičari, historičari, biolozi, hemičari, geografi itd.

Dakle, sva djeca imaju potrebu da škola koju pohađaju bude po njihovoj mjeri, po mjeri svih, da svima pruži šansu za afirmaciju, dokazivanje, potvrđivanje, a škola će to biti ako je rad u njoj organiziran po modelu uključi me, koji pretpostavlja aktivno uključivanje učenika kako u nastavni proces, tako i u slobodne i druge aktivnosti koje se organiziraju i ostvaruju u školi.

U razvijenim i demokratskim zemljama svijeta prihvaćena je odgovornost i obaveza društva da maksimalno omogući razvoj potencijala svakoga pojedinca, dajući podjednake mogućnosti svima kako u razvijanju sposobnosti tako i u razvijanju vještina i navika. Pored kognitivnih sposobnosti, škola ima obavezu da kod učenika razvija smisao za saradnju, emocionalnu uravnoteženost, sposobnost prilagodljivosti, samouvjerenosti i sigurnosti u prevazilaženju svih problema na koje nailaze.

Nastavni planovi i programi, mišljenja su praktičara, i dalje su preopširni, opterećeni činjenicama i faktografijom, neprilagođeni sposobnostima i mogućnostima učenika, bez obzira o kojem se nivou radi.

Šarenilo koje vlada u izdavačkoj udžbeničkoj literaturi najviše pogađa one za koje je namijenjena, a o apsurdima o kojima se puno 
govorilo i govori u školama i sredstvima informiranja suvišno bi bilo ponavljati.

Savremeni psihološko-pedagoški aspekti odgojno-obrazovnoga rada sve više nameću potrebu realizacije individualizacije nastavnog procesa, kako bi se u što većoj mjeri uvažile realne individualne razlike među učenicima. Vrlo aktuelna je i ideja o integraciji kojom se prevazilaze barijere prevladavanja društvenog izdvajanja i izoliranja djece s teškoćama u razvoju. Integracija djece s teškoćama u razvoju u redovna odjeljenja omogućuje pozitivnu identifikaciju koja je, također, pretpostavka za uspjeh u učenju, radu i životu. Sve su to osnovne pretpostavke za motivaciju djece na učenje i rad bez kojih nema dobrih rezultata ni kod djece koja nemaju teškoće u razvoju, i s tog aspekta ne spadaju u kategoriju djece s posebnim potrebama.

\section{Odnos prema kreativnim, darovitim i talentiranim učenicima}

Prema istraživanjima iz ove oblasti, utvrđeno je da intelektualna darovitost ne može biti sinonim za kreativnost i stvaralaštvo.

Iako je dokazano da je stvaralaštvo povezano $s$ visokim sposobnostima, između njih se ne može staviti znak jednakosti. To zbog toga, što postizanje visokih rezultata u jednoj oblasti zahtijeva, pored intelektualne darovitosti, i druga svojstva ličnosti kao što su: stavovi, navike, interesi i sl.

Dokazano je da darovitost i kreativnost obuhvataju znatno širi sklop osobina ličnosti, nego što su to samo intelektualna svojstva. To znači da je darovitost i kreativnost određena cjelokupnom strukturom ličnosti u kojoj kognitivne sposobnosti predstavljaju samo jedan aspekt ličnosti.

Da se pitanju kreativnosti učenika sve više poklanja odgovarajuća pažnja, potvrđuje i nedavno održana Prva smotra mladih umjetničkih talenata FBiH u sklopu projekta Kreativne radionice za mlade u FBiH - Stvaralaštvom protiv maloljetničke delinkvencije. Očekivati je da će ovakvi i slični projekti doprinijeti da se u odgojno-obrazovnome radu kreativnoj djeci osiguraju uvjeti za razvoj njihovih potencijala.

Prema Furlanu, za intelektualno darovitu i kreativnu djecu koriste se izrazi nadaren kao pasivnije obilježje od darovit, a 
talentirana djeca posjeduju sposobnosti za specifična područja. Tako razlikujemo talente za matematiku, jezik, umjetnost likovnu ili muzičku, talente za informatiku, historiju i sl.

Ejub Ćehić navodi niz psihološko-pedagoških pretpostavki odgoja i obrazovanja djece s posebnim potrebama ističući potrebu poznavanja i uvažavanja.

Profesor Ćehić ističe da postoje intelektualne posebnosti koje se kod djece ispoljavaju kroz talentiranost, nadarenost i obdarenost.

Za talentiranu djecu ističe da ih karakterizira natprosječna sposobnost i kreativnost za umjetničke, sportske i praktične aktivnosti. Nastavnici trebaju znati da ovi učenici ne pokazuju interes za apstraktno-teorijske sadržaje i svaka prisila da ih u cijelosti savladaju, kod učenika stvara averziju i za sadržaje za koje su svojim sklonostima predodređeni.

Za nadarenu djecu je karakteristično da posjeduju natprosječne sposobnosti za određenu oblast društvenih djelatnosti (smisao za društvene nauke, ali i smisao za tehničke nauke, prirodne nauke, smisao za strane jezike).

Veoma je značajno blagovremeno otkriti i podsticati razvoj ovih sposobnosti i usmjeravati dijete u izboru buduće srednje škole. Upis srednje škole koja je u suprotnosti s dječijim sposobnostima, dovodi do bezvoljnosti u učenju, a time i do neuspjeha. Tako i ova djeca mogu postati djeca s posebnim potrebama.

Obdarena ili darovita djeca posjeduju sposobnosti za sve nastavne predmete i bez većih teškoća savladavaju sve obaveze $u$ školi. Već je istaknuto mišljenje I. Furlana da nadarenost ima nešto pasivnije obilježje u odnosu na darovitost, pa je ovu djecu potrebno što ranije usmjeravati prema određenim područjima, kako bi se intenzivnije njima bavili i stvarali pretpostavke za pravilan izbor budućeg zanimanja. ${ }^{2}$

M. Čudina-Obradović pod nadarenošću podrazumijeva neobičnost, iznimnost ponašanja, koja se ogledaju u kvalitetnijem,

2 E. Ćehić, Psihološko-pedagoške pretpostavke odgoja i obrazovanja djece sa posebnim potrebama, Porodica i dijete, 1998., 3/18. 
boljem, značajnijem rezultatu ili produktu, nego što postižu ostali pojedinci sa sličnim karakteristikama. ${ }^{3}$

Pitanje rada s talentima, nadarenim i obdarenim istraživali su i studenti Pedagoškog fakulteta u Bihaću pri izradi svojih diplomskih radova. Jedno takvo istraživanje provedeno je u cilju utvrđivanja mišljenja nastavnika o problemima odgoja i obrazovanja superiornih učenika. Tako 66,66 \% nastavnika uključenih u istraživanje smatra da je talentiranost, nadarenost i obdarenost pod utjecajem inteligencije. Prema njihovom mišljenju, sredina i genetska osnova ili naslijeđe imaju manji utjecaj na ova svojstva. Oko 83,3 \% anketiranih nastavnika smatra da dosadašnja osmogodišnja osnovna škola ne pruža dovoljne mogućnosti za napredovanje talenata, darovitih i obdarenih učenika, a $58,3 \%$ ih smatra kako će devetogodišnje školovanje donijeti poboljšanje u edukaciji darovitih.

Zanimljivo mišljenje anketiranih nastavnika je o vrijednosti udžbenika kada su u pitanju talenti, nadareni i obdareni učenici. Oko $75 \%$ nastavnika smatra da samo neki udžbenici zadovoljavaju potrebe ovih učenika. Njih 41,6 \% smatra da bi bolja opremljenost škole značajno doprinijela adekvatnom tretmanu i napredovanju superiornih učenika.

Iako su ovo skromni rezultati, vrijedni su pažnje tim prije što se vrlo malo ili nikako ne poklanja adekvatna pažnja ovoj kategoriji učenika koji, također, imaju svoje posebne potrebe. ${ }^{4}$

Maslov je još prije 50 godina tvrdio da kreativnost postoji u svakoj osobi, premda će u većini ostati prigušeni materijal. Nije li to slučaj i sa velikim brojem obdarenih učenika kod kojih njihova kreativnost, sposobnosti, mogućnosti i znanje ostaju prigušeni. ${ }^{5}$

O tome kako podsticati kreativnost učenika pisao je Ismet Dizdarević. Između ostaloga, ističe važnost iznalaženja i prakticiranja

3 M. Čudina-Obradović, Nadarenost, razumijevanje, prepoznavanje, razvijanje, Školska knjiga, Zagreb, 1991.

${ }^{4}$ E. Odobašić, Daroviti učenici u razrednoj nastavi i rad s njima, Diplomski rad, Pedagoški fakultet, Bihać, 2007.

${ }^{5}$ A. H. Maslov, Creativity and its cultivation, Harper, New York, 1959. 
odabranih načina vođenja kreativnih učenika. Istraživanja su pokazala da od načina vođenja kreativnih učenika zavisi i njihov uspjeh. ${ }^{6}$

Zar nije najbolji primjer uspjeh Bišćanki, članica Plesnog kluba Virus iz Bihaća na Svjetskom prvenstvu koje je održano u Njemačkoj, gdje su u konkurenciji 26 nacija i 2. 600 takmičara osvojile zlatnu, srebrenu i brončanu značku. Tako je Irma Memagić postala svjetska juniorska prvakinja u show danceu, Ajna Kujundžić u kategoriji solo djeca od 38 takmičarki osvojila drugo mjesto i Ilvana Smajić i Sara Rizvić treće mjesto.

Voditeljica i koreografkinja u Plesnome klubu Virus iz Bihaća, Dijana Jajčević, zaslužuje veliku zahvalnost i pohvale, jer je sa svojim članicama bila najbolji ambasador države Bosne i Hercegovine na ovome Svjetskom prvenstvu u plesu, jednom od najstarijih načina čovjekovog izražavanja i predstavljanja igre tijela, načina predstavljanja emocija snage i života. Njihov je uspjeh poruka kako se adekvatnim motiviranjem $\mathrm{i}$ dobro odabranim načinom vođenja, može mnogo učiniti na planu pravilnog razvoja mladih.

\section{Učenici s posebnim potrebama i odnos prema njima}

Od neprocjenjivog značaja za razvoj ličnosti djeteta, jeste način života majke u periodu trudnoće, a posebno u periodu prenatalnog razvoja buduće bebe. Mnoge mlade majke, ne želeći se odreći nekih veoma štetnih užitaka, ne žele vjerovati u njihovu štetnost i nastavljaju konzumirati alkohol, pušiti duhan, a nisu rijetke pojave i korištenja opojnih sredstava, uslijed čega na svijet donose djecu s riziko faktorima. Za razvoj ove djece u kasnijem periodu značajnu ulogu mogu odigrati okolina u kojoj žive i način njihovog odgajanja.

Pretjerano konzumiranje raznih lijekova, aspirina, barbiturata, nikotina, alkohola vrlo nepovoljno utječe na razvoj embrija, fetusa, a kasnije na ukupni razvoj djeteta koje najčešće izrasta u riziko dijete. Ova djeca najčešće imaju posebne potrebe i posebne zahtjeve za svoj normalni razvoj. Kod njih se često javljaju riziko faktori među kojima i oštećenje vida, oštećenje sluha, govorni poremećaji, pojave tjelesne invalidnosti, različiti organski poremećaji, hronična oboljenja i sl. Kod takvih osoba se izrazitije mogu zapaziti posebne potrebe.

${ }^{6}$ I. Dizdarević, Najsposobniji su najbolji, Prosvjetni list, 1998. 
Od specifičnost u stepenu oštećenja, u vrsti i stepenu traume, zavisit će i načini rada i djelovanja odgajatelja; strategije koje će koristiti u radu s njima, a koje će u rezultatu imati pozitivne ishode $\mathrm{u}$ učenju i ponašanju.

Kroz uvažavanje posebnih potreba učenika, nastavnici bi morali njegovati što originalniji stil učenja svakoga učenika ponaosob, jer se time razvija kognitivna sfera, stil mišljenja i prilaženja u rješavanju problema oslobođena od stereotipa i šablona - stabilizira se emocionalna uravnoteženost i socijalna prihvatljivost učenika.

Uloga nastavnika u identifikaciji učenika kojima je potreban poseban tretman je ogromna i nezamjenjiva. Radeći svakodnevno s djecom, nastavnici kroz redovnu i ostale vidove nastave, vrlo uspješno otkrivaju djecu s posebnim potrebama.

Kada govorimo o posebnim potrebama učenika u učionici, ne smijemo izgubiti iz vida činjenicu, da gotovo sva djeca imaju određene posebne potrebe i sl. Ipak se mora konstatirati da je rad s djecom koja imaju teškoće u razvoju bile one fizičke ili psihičke prirode, mnogo složeniji i zahtjevniji. Nisu rijetki slučajevi da se u redovna odjeljenja uključuju djeca s vrlo složenom i kompliciranom dijagnozom koja je gotovo nepoznata nastavniku, kako bi se uvažavao princip inkluzije. Navodimo jedan takav slučaj koji je istražen u okviru izrade diplomskoga rada studenta Pedagoškog fakulteta Univerziteta u Bihaću. Nastavnica je četiri godine radila s učenikom čija je inteligencija bila popraćena odstupanjem u psihomotornom, govornom, emocionalnom i socijalnom razvoju. Učenik je bio sa neurorizičnim faktorima $i$ imao je odstupanja $u$ razvoju na planu psihomotorike. Uz pomoć stručnjaka iz ove oblasti, posebno defektologa i logopeda koji su imali iskustvo u radu s djecom u specijalnim školama, individualiziranom nastavom i uz maksimalno uloženi trud nastavnika u svim nastavnim predmetima, učenik je uspio usvojiti određena znanja. U ovome radu nije izostala podrška roditelja. Na kraju IV razreda učenik nije uspio u potpunosti savladati čitanje, pa su roditelji zamolili nastavnicu da učenik ponovi IV što je Nastavničko vijeće i stručna komisija odobrila i pohvalila molbu i 
želju roditelja koji istrajavaju u svojoj namjeri i cilju da pomognu djetetu. $^{7}$

Za uspjeh u učenju značajno je da u odjeljenju vlada pozitivna socioemocionalna nastavna klima. Povoljna klima u razredu pogoduje interaktivnom načinu rada učenika i nastavnika koji maksimalno uvažava mogućnosti, sposobnosti i emocionalna stanja učenika. Do takvih rezultata došli su i studenti koji su u obradi teme za izradu diplomskog rada provodili mala operativna istraživanja. Navodimo neke primjere koji to potvrđuju. ${ }^{8}$

\section{Slučaj D. S.}

D. S. potječe iz potpune porodice. Porodica je radnička, domicilna, gradskoga porijekla. Stanuje u porodičnoj kući, roditelji su u radnome odnosu u privatnom sektoru, što upućuje da je materijalno stanje obitelji zadovoljavajuće.

Uža obitelj ima 5 članova, D. S. je drugo dijete po redu, ima 9 godina, učenica je IV razreda osnovne škole. Rođena je na vrijeme u bolnici, normalno se psihički razvijala. Odnosi u obitelji su doskora bili skladni. Zajedno su i otac i majka brinuli i redovno dolazili $u$ školu na informacije, sve do prošle godine kada su se pojavili zdravstveni problemi s mlađim sinom. Tada su svu pažnju uputili prema njemu. Od tada D. S. počinje da iskazuje nedolično ponašanje u razredu prema drugim učenicima.

U osnovnu školu upisana je sa navršenih šest godina. Od početka pokazuje dobar uspjeh $i$ često se ne snalazi u timskome radu. Druga djeca je od samoga početka ne prihvataju, odbacuju je iz svih aktivnosti. Posebno djevojčice koje je odbacuju i ne žele uopće da se druže s njom. Majka je u razgovoru zaprepaštena jer S. uvijek daje izgovore kako drugi nju napadaju i uznemiravaju. Također, majka je razočarana i s lošim uspjehom $S$.

Majka nije zadovoljna ni sa radom nastavnice i izjavila je: 'Nastavnica previše traži od njih i pokazuje arogantno ponašanje

\footnotetext{
${ }^{7}$ S. Toromanović, Učenici s posebnim potrebama u razrednoj nastavi $i$ rad s njima, Diplomski rad, Pedagoški fakultet, Bihać, 2007.

${ }^{8}$ Ibid.
} 
prema S. koja se uvijek osjeća poniženo na časovima od strane nastavnice.'

U intervjuu S. navodi: 'Ne volim da učim, dosadno mi je na časovima, teško mi je gradivo, više volim da radim nešto drugo.'

S. je frustrirana zbog zapostavljanja od strane roditelja, te svojim neuspjehom $i$ nedoličnim ponašanjem želi privući pažnju $i$ roditelja i nastavnice.

S. nema puno prijatelja niti u školi niti kod kuće. Kad pokušava da se približi nekome u razredu, često izabire dječake za igru i biva uvučena u tuče. To je do sada bio čest slučaj što je izazvalo burne reakcije roditelja. Majka je znala da ulazi u učionicu $i$ da uvodi pravdu, te je optuživala drugu djecu da zlostavljaju njenu kćerku, a da nastavnica to sve dopušta. Razred je veoma kvalitetan s najboljim uspjehom na nivou škole, rade po savremenim metodama, timski $i$ često ostvaruju visoke rezultate na školskim takmičenjima.

O. V. ima devet godina. Potječe iz nepotpune obitelji. Otac ih je napustio $i$ otišao nakon rođenja drugog djeteta (O. N. ima četiri godine). Otac je bio fizički radnik, rođen je 1972. godine, često je izbivao od kuće, materijalna situacija bila je jako loša i još uvijek je. Majka je rođena 1975. godine, nepismena je i bez završenog razreda osnovne škole. Po zanimanju je domaćica. Nikada nije zasnivala radni odnos. Majka, također, pokazuje znake zaostalosti u mentalnom razvoju. Stambeni uvjeti od početka su jako loši. Često mijenjanje mjesta stanovanja, škole $i$ okoline, stvaralo je poteškoće oko same socijalizacije učenice $V$.

Mišljenje stručnog tima o V:

$V$. je rođena u bolnici uz ljekarsku intervenciju. Majka je imala težak porod. Za kalendarski uzrast fizički je normalno razvijena. Od samoga početka nije pokazivala želju za školom, nije se pripremala za nastavu. Jako je netolerantna na frustracije i agresivna je. Zbog nedovoljnoga kućnog odgoja i nadzora treba s njom duže raditi. Za V. je karakteristična i sljedeća konstatacija stručnoga tima: 'Sa njom se kontakt otežano uspostavlja. Po prirodi je zatvorena, škrta na riječima, oskudnoga znanja. Nema razvijene kulturne, radne ni higijenske navike.' 


\section{Mjere koje treba poduzeti}

Zbog specifične porodične situacije u kojoj majka kao nepismena žena nije u stanju voditi brigu o svojoj djeci, sobzirom da se radi o zapuštenoj i zanemarenoj djevojčici, nužno bi bilo poduzeti korake zbrinjavanja i otvorenu zaštitu. Sistematski rad u okviru socijalno-pedagoške i psihološke pomoći kao i preventivni rad na suzbijanju pojavljivanja delinkventnog ponašanja, može samo pomoći učenici. Čestom promjenom škole stanje se samo pogoršavalo; imala je velike ispade agresije, $s$ drugom djecom se nije slagala, koristila bi svaku priliku da prkosi nastavnici. Međutim, dolaskom iz područne seoske škole u gradsku, stanje se promijenilo. No, poremećaje u ponašanju kod nje uočavaju normalno razvijeni vršnjaci i zato je često ne prihvataju. Intenzivno pratiti dalji tok i redovito pružati pomoć. ${ }^{9}$

Socioemocionalna klima u razredu značajno može utjecati na pozitivne ishode učenja i na ponašanje učenika. Poznato je da emocionalna inteligencija, uz akademsku, doprinosi uspješnoj komunikaciji, razumijevanju i saradnji, podupire toleranciju i fleksibilnost što sve dolazi do izražaja kako u odgojno-obrazovnome radu tako i u svakodnevnim životnim okolnostima. Za socioemocionalnu klimu u razredu odgovorni su odgajatelji, učenici i roditelji. Svi moraju znati njen značaj i moraju ispunjavati svoje obaveze i odgovornosti. Tako će se stvarati atmosfera u kojoj svaki učenik ima podjednaku šansu za afirmaciju u skladu sa svojim mogućnostima. Navedeni primjeri iz prakse to i potvrđuju.

Istraživanja su potvrdila sve veću potrebu praćenja i rada djece koja imaju posebne potrebe bilo zbog naglašenih potencijala, bilo zbog teškoća u razvoju. Tako, npr. na području USK-a anketirano je 127 nastavnika razredne i predmetne nastave i njih $99 \%$ se izjasnilo da uočavaju prisustvo posebnih potreba kod učenika s kojima rade. Gotovo su svi izjavili da je to veoma značajan problem. Posebno su zanimljiva mišljenja nastavnika u vezi $\mathrm{s}$ identifikacijom kategorija učenika s posebnim potrebama. $\mathrm{S}$ tim u vezi, zapažena je približno ujednačena distribucija kako nadarenih, tako i učenika iz kategorije izbjeglih, djece s poremećajima u ponašanju, djece povratnika, te učenika s ograničenim sposobnostima. Rezultati istraživanja pokazuju

\footnotetext{
9 S. Halkić, Socioemocionalna klima kao faktor razvoja učenika, Diplomski rad, Pedagoški fakultet, Bihać, 2009.
} 
da porodica nema znatnijeg udjela $\mathrm{u}$ identificiranju posebnih potreba kod svoje djece ( oko $50 \%$ ).

Čak ni nastavne aktivnosti u tome nemaju odlučujuću ulogu. Optimistična je izjava anketiranih nastavnika kako uvažavaju posebne potrebe djece i kako uspješno iznalaze rješenja za prevazilaženje otkrivenih poteškoća. Iako većina nastavnika ističe postojanje posebnih potreba kod djece i u normalnim životnim okolnostima, ipak njih oko $80 \%$ anketiranih smatra da su ove pojave prisutnije kod djece koja su preživjela ratne strahote.

\section{Edukacija nastavnika usmjerena na pružanje pomoći svima}

Svaki pojedinac treba i može biti maksimalno angažiran kako bi na najbolji način razvijao i iskoristio vlastite potencijale. Zato im treba dati dovoljno vremena, informacija, a posebno povratnih informacija koje ih obavještavaju o napredovanju. Prevaziđeno je shvatanje da je interes osnovni preduvjet za učenje. Informacija o napredovanju, o postignutim rezultatima i potvrda uspješnosti $u$ određenoj aktivnosti, izaziva interes za edukaciju i za odabranu aktivnost.

S tim u vezi Pedagoški zavod USK-a u svojim programskim aktivnostima radi intenzivno na stručnome usavršavanju nastavnika $u$ cilju njihovog uspješnijeg rada s učenicima različitih kategorija. Zavod organizira seminare, radionice za razmjenu iskustava, a neposrednim kontaktima na terenu stručni savjetnici i saradnici Zavoda prate rad i pružaju pomoć nastavnicima u radu s različitim kategorijama učenika. Pomoć u radu daju i Okvirni programski sadržaji u Nastavnim planovima i programima koje za 9-godišnje osnovno školovanje izrađuje Ministarstvo obrazovanja, nauke, kulture $i$ sporta USK-a. Okvirni programski sadržaji daju osnovu za izradu individualnog edukativnog programa nastavnika za rad $\mathrm{s}$ djecom koja imaju teškoće u razvoju.

Do trenutka pisanja ovoga članka, povodom kreiranja baze podataka u Pedagoškom zavodu USK-a o djeci s teškoćama u razvoju pristigli su podaci o njihovom broju. Tako su od 71 osnovne i srednje škole podaci stigli iz 60 osnovnih i srednjih škola, te se od 11 škola podaci još očekuju. Prema ovim podacima na području Pedagoškog 
zavoda USK-a ima 424 učenika koji su registrirani kao učenici s teškoćama u razvoju. Njih 402 su u osnovnoj školi, a u srednjim školama ih je 22. U 4 osnovne i 4 srednje škole utvrđeno je da nema učenika s teškoćama u razvoju.

Ovo su dragocjeni podaci, jer omogućavaju mobilizaciju svih aktera u odgojno-obrazovnome radu kako bi se blagovremeno i stručno pružila pomoć ovoj djeci u savladavanju barijera koje prate učenje i napredovanje. Međutim, s pravom se postavlja pitanje šta je s podacima o učenicima s posebnim potrebama i ako ih ima, uključuju li različite kategorije djece. U Pedagoškom zavodu USK-a provedeno je istraživanje o inkluziji u osnovnim školama USK-a. Prema rezultatima ovoga istraživanja u osnovnim školama USK-a ima ukupno 463 učenika $\mathrm{s}$ posebnim potrebama, od čega 120 učenika $\mathrm{s}$ dokumentacijom da spadaju u kategoriju učenika $\mathrm{s}$ posebnim potrebama i za njih je urađen Prilagođeni nastavni plan i program, te 343 učenika bez odgovarajuće dokumentacije i za njih nema prilagođenog nastavnog plana i programa.

Svi su oni $\mathrm{u}$ kategoriji učenika $\mathrm{s}$ teškoćama $\mathrm{u}$ razvoju, mentalnom, tjelesnom ili drugom vrstom oštećenja i poremećaja. Ovdje nema podataka o djeci s posebnim potrebama koja nemaju nikakvih smetnji u razvoju. Takvih učenika je mnogo, jer svako od nas ima posebne potrebe pa i svaki učenik, bio s teškoćama ili bez teškoća u razvoju, ima svoje posebne potrebe koje treba uvažavati. Vjerujem da će naredna istraživanja u Zavodu biti usmjerena i na ovu djecu, pošto to život nameće. Autorice istraživanja svakako zaslužuju zahvalnost i pohvalu, jer su na ovaj način skrenule pažnju javnosti na značajna pitanja tretmana djece u našoj savremenoj školi koja, pored ostalog, ukazuju i na prava djeteta na školovanje po mjeri svih. Saradnja Pedagoškog zavoda, centara za socijalni rad, centara za mentalno zdravlje, Univerziteta u Bihaću, prije svega Pedagoškog fakulteta u narednim istraživačkim aktivnostima još će više doprinijeti stručnom i naučnom unapređivanju odgoja i obrazovanja i stvaranju škole po mjeri svih. ${ }^{10,11}$

\footnotetext{
${ }^{10}$ V. Smailagić - S. Demirović, Inkluzija u osnovnim školama USK-a, Rezultati istraživanja, JU Pedagoški zavod USK-a, Bihać, 2009.

11 Dio podataka pripremio i obradio A. Kreso, stručni saradnik za psihološka i defektološka područja.
} 
Svi koji se na bilo koji način bave odgojem i obrazovanjem djece pa i djece s posebnim potrebama preporučuje se da budu istrajni, strpljivi, da rade s puno razumijevanja, volje, napora. Takav odnos značajno će doprinijeti pozitivnim ishodima učenja.

Timski rad i međusobna razmjena iskustava u značajnoj će mjeri pomoći izboru pravih strategija u prilagođavanju zahtjeva nastavnika sposobnostima i mogućnostima svakog učenika što će u rezultatu imati bolji uspjeh u učenju i radu. Jačati samopouzdanje, vratiti vjeru u vlastite mogućnosti, ojačati optimizam ustvari znači uspjeh, jer optimizam predstavlja jedan od važnih elemenata za ostvarenje određenog cilja, dakle i uspjeha u učenju. Optimizam je, ustvari, način kako ljudi shvataju svoje uspjehe i neuspjehe. Biti optimista znači uspješno se braniti od zapadanja u stanje depresije, apatije, beznađa i očaja. Pri tome je veoma važno da optimizam bude realan, ostvariv, a ne naivan što dovodi do kontraproduktivnih efekata. Optimistične učenike karakterizira izražen zanos i vjera da će se trenutačni problemi uspješno savladati bez obzira na teškoće i prepreke. Dakle, optimistični učenici uspješno ostvaruju motivacioni ciklus, jer na putu do ostvarenja cilja uspješno savladavaju sve barijere što nije slučaj sa pesimističnim učenicima. Vjerovanje u mogućnost savladavanja neuspjeha zahvaljujući faktorima koji se mogu kontrolirati i mijenjati uz pomoć psihičkih i fizičkih svojstava koje osoba posjeduje. To potvrđuju istraživanja koja je proveo Seligman na studentima Pensilvanije Univerziteta koja su potvrdila da optimistični studenti postižu bolje rezultate u savladavanju studija od pesimističnih studenata. Dakle, sposobnosti koje osobu motiviraju da uči na vlastitim greškama i da uporno iznova pokušavaju da riješe problem svojstvena je optimistima. Zaista Allah neće promijeniti situaciju jednog naroda dok oni ne promijene ono što je u njihovim dušama. $\left(\right.$ Er-Ra'd. 11) ${ }^{12}$

U svakodnevnome radu i komunikaciji na relaciji: škola nastavnik; nastavnik -učenik; direktor - nastavnik - učenik, neminovno se javljaju kritični periodi kad ponestane snage, volje, koncentracije u radu. Psiholozi i pedagozi u takvim situacijama predlažu sljedeće:

\footnotetext{
${ }^{12}$ M. Mubejjid, Nauči vladati svojim emocijama, Emocionalna inteligencija, Naučni $\mathrm{i}$ islamski pogledi, Dobra knjiga, d.d., Sarajevo, 2008.
} 
- Misliti pozitivno barem na ono što nam je ostalo pa makar to bio i samo život;

- Sami sebe uvjeravati da će kritični trenuci krize proći, dakle treba ih tih trenutaka izdržati i nastojati ublažavati;

- Sjetiti se da od gorega ima gore i svoju pažnju usmjeriti na ono što nam čini zadovoljstvo, na svijetle strane života;

- Strah koji nas ponekad prati, tuga, anksioznost (tjeskoba) su prolazni;

- Sjetiti se da i drugi imaju sličnih ili većih problema i nastoje da ih uspješno rješavaju. I tako se može utjecati na smanjenje jačine nepoželjnih stanja;

- Razgovarati sa osobama koje imaju optimistička gledanja, koje su sklone ohrabriti, predlagati pozitivna rješenja;

- Neke situacije, pojave, stanja su neizbježna i tako ih treba prihvatiti, jer će se odvijati htjeli mi to ili ne. ${ }^{13}$

Kada na ovakav način analiziramo svakodnevne probleme, potrudimo se da i učenike s kojima radimo na sličan način gledamo, i da im pomognemo da lakše prebrode krize i poteškoće na koje nailaze i kroz koje prolaze.

Analogno tome, i direktori škola bi trebali imati volje, znanja i sposobnosti da pomognu svojim nastavnicima; trebaju primijetiti da je neko od nastavnika u posljednje vrijeme zabrinut, potišten, da ne izvršava obaveze kao do sada, da je postao frustriran, konfliktan, da se nalazi u teškom stanju, jer možda ima teške porodične probleme i tome slično. Svako pokazivanje interesa i brige, ispoljavanje volje da se pruži pomoć i razumijevanje od strane nastavnika ima izuzetan značaj u prevazilaženju problema.

\section{Zaključak}

U sistemu odgoja i obrazovanja neophodno je ravnopravno tretirati sve učenike. Bez obzira na individualne razlike među njima, kao posljedicu razlika $\mathrm{u}$ tjelesnoj konstituciji, $\mathrm{u}$ intelektualnim

\footnotetext{
${ }^{13}$ G. Greene, Nove paradigme za stvaranje kvalitetne škole, Alineja, Zagreb, 1996.
} 
sposobnostima, u dimenzijama ličnosti, njihovim mogućnostima, interesima, željama i sl. U svakodnevnom nastavnom procesu i sveukupnim aktivnostima dužni smo svima posvetiti adekvatnu pažnju. Zapostavljanje bilo koje kategorije učenika je neopravdano, jer svi učenici imaju svoje posebne potrebe i uvažavanje specifičnosti onih koji imaju teškoće u razvoju jednako nas obavezuje da uvažavamo i one koji su u kategoriji talenata, nadarenih i obdarenih. Jedino ravnopravnim odnosom i tretmanom škola može ostvariti svoju istinsku funkciju i biti škola po mjeri svih. Takvim odnosom izbjeći ćemo štetne posljedice koje zasigurno najviše pogađaju učenike, ali i društvo u cjelini. Formiranje baze podataka o djeci $\mathrm{s}$ teškoćama $\mathrm{u}$ razvoju, djeci s posebnim potrebama, o superiornim na kojoj se intenzivno radi u Pedagoškom zavodu USK-a, omogućit će potpuniju individualizaciju nastave, uvažavanje učeničkih potencijala što će u rezultatu imati bolje i realnije ishode učenja učenika. Valja imati u vidu različita stajališta posebno kada je riječ o inkluziji talenata, nadarenih i obdarenih. Protivnici inkluzije koja uključuje i ove učenike, a među njima su brojni nastavnici i roditelji ovih učenika, smatraju da se ovi učenici ne mogu optimalno razvijati u školi i odjeljenjima, gdje se inkluzija provodi bez uvažavanja individualnih razlika među njima. Takva škola nije škola po mjeri svih, smatraju pristalice ovakvoga shvatanja.

\section{Literatura:}

1. Atkinson (Hilgard), Uvod u psihologiju, Naklada Slap, Jastrebarsko, 2007.

2. Dizdarević, I., Agensi socijalizacije ličnosti, Prosvjetni list, Sarajevo, 2002.

3. Čudina-Obradović, M., Nadarenost, razumijevanje, prepoznavanje, razvijanje, Školska knjiga, Zagreb, 1991.

4. Ćehić, E., Psihološko-pedagoške pretpostavke odgoja i obrazovanja djece sa posebnim potrebama, Porodica i dijete, 3/18., 1998.

5. Greene, G., Nove paradigme za stvaranje kvalitetne škole, Alineja, Zagreb, 1996.

6. Ilić, M., Interaktivno obučavanje nastavnika za individualizaciju učenja čitanja $i$ pisanja u inkluzivnoj nastavi. U: Dmitrović, E. (uredio), Individualizacija $i$ inkluzija u obrazovanju, Zbornik radova, str. 14 - 31., Sarajevo, 2006. CES Programme Finnish CO - operation in the Education Sector of Bosnia and Herzegovina 2003 - 2006.

7. Mubejjid, M., Nauči vladati svojim emocijama, Emocionalna inteligencija, Naučni i islamski pogledi, Dobra knjiga, d.d., Sarajevo, 2008. 
8. Muminović, H., Određenje i identifikacija nadarenosti. U: Pašalić-Kreso A. (urednik), Inkluzija u školstvu Bosne i Hercegovine, Zbornik radova, str. 138 153., Sarajevo, 2003. TEPD - Teacher education and professional development i Odsjek za pedagogiju Filozofskog fakulteta u Sarajevu.

9. Stefanović, D., Metodologija rane dijagnostike $i$ rehabilitacije dece ometene $u$ psihofizičkom razvoju, Institut za dokumentaciju zaštite na radu Edvard Kardelj, Niš, 1980.

10. Sternberg, Robert J, Kognitivna psihologija, Naklada Slap, Jastrebarsko, 2005.

11. Zekić, S., Neke mogućnosti identifikacije darovitih učenika u višim razredima osnovne škole, Naša škola, 1-2/63 - 71., 1987.

12. Zvonarević, M., Socijalna psihologija, Školska knjiga, Zagreb, 1989. 
PROF. DR. OSMAN RAMIĆ, P.H.D.

EQUAL TREATMENT OF SUPERIOR, AVERAGE AND
CHILDREN WITH DISABILITIES IN MODERN SCHOOL

\section{SUMMARY}

In theory and in practice of modern educational work issues related to treatment of children with special needs are unavoidable. Under this term, it is usually thought about pupils who for various reasons fall behind in studies, in performing of school duties and in achieving positive learning outcomes. Separation of these pupils and other ones whose special needs are an expression of desire for greater knowledge, for more productive and fruitful work and learning, is very rarely or even never done. In order to fulfil the needs of curriculum teachers sometimes focus their attention on the first category of students and don't leave space or time for others that are as important as they are. The question is - are talented students neglected? This is a very important issue regarding their future.

Key words: sources of learning, emotional stability, inclusion, integration, talents, talented, special needs, impairments in development, creativity, optimism. 
الأستاذ الدكتور عثمان راميتش

\section{المساواة في التعامل مع الأطفال المتفوّقين، والمتوسّطين والأطفال ذوي الاحتياجات الخاصة في المدرسة المعاصرة}

\section{خلاصة البحث}

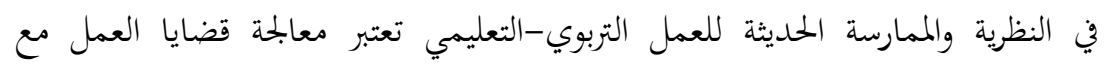

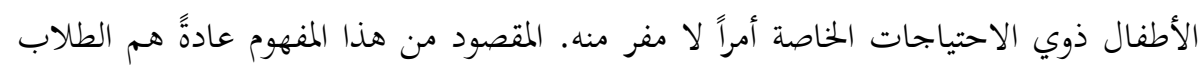

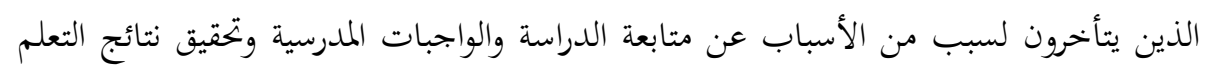
الإيجابية. التفريق بين هؤلاء الطلاب والطلاب الذين لديهم رغبة خاصة في المزيد من المعرفة

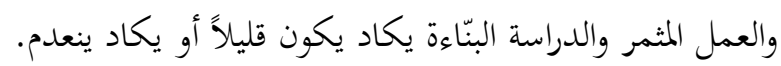
بدافع الرغبة لتلبية متطلبات المناهج الدراسية، يولي المعلمون وبانتظام اهتمامهم للفئة الأولى من الطلاب حيث لا يتركون المحال للفئة الثانية، مع أغا لا تقلّ أهميةً عن الأولى. السؤال

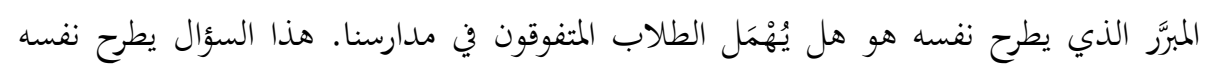
بسبب واضح، وهو من أجلهم ومن أجل مستقبلهم.

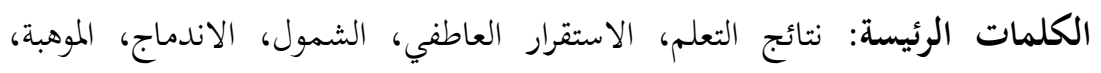
الموهوبون، ذوو الاحتياجات الخاصة، الإعاقة في النمو، الإبداع، التفاؤل. 